\title{
Birds and mammals of the Bukit Barisan Selatan National Park, Sumatra, Indonesia
}

\author{
Timothy G. O'Brien and Margaret F. Kinnaird
}

Bukit Barisan Selatan National Park in south-west Sumatra is one of the largest protected areas in Sumatra and thus of considerable importance to the conservation of biodiversity in Indonesia. Until recently, little was known of the wildlife in the park. The authors' surveys document the presence of an intact community of the birds and mammals known to occur in lowland Sumatran rain forests. While hunting and collection of forest products threaten a number of plant and animal species in the park, the primary threat to the park's integrity is from agricultural encroachment and expansion of enclaves beyond their boundaries. The future survival of Bukit Barisan National Park and its wildlife requires that active measures be taken to curb non-sustainable exploitation of plants and wildlife. It will also be necessary to resolve land-use conflicts with communities in, and adjacent to, the park.

\section{Introduction}

Bukit Barisan Selatan National Park (BBSNP) is the third largest protected area (3568 sq km) on the Indonesian island of Sumatra. Located in the extreme south-west of Sumatra $\left(104^{\circ} \mathrm{E}\right.$, 50 'S), the park spans two provinces, Lampung and Bengkulu, extending from the southern tip at Tanjung Cina to more than $120 \mathrm{~km}$ north along the Barisan Mountain Range (Figure 1). The BBSNP contains some of the largest intact tracts of lowland rain forest remaining in Sumatra and serves as the primary watershed for south-west Sumatra (FAO, 1981). Most of the Park (82 per cent) lies in Lampung Province, the most densely populated, poorest province of Sumatra, and one undergoing the most rapid forest conversion (Whitten et al., 1987). The park's long, thin shape results in $c$. $700 \mathrm{~km}$ of boundaries, and encroachment by illegal logging and cultivation are recurrent problems.

Despite its large size and importance, BBSNP has not been surveyed systematically for mammals or birds; however, it is believed to be an important refuge for a major portion of Sumatra's mammal and bird fauna (FAO, 1981). Early reports indicate the pres- ence of Sumatran rhinoceros*, Asian elephant, tiger, clouded leopard, Malayan sun bear, serow and Indian wild dog (FAO, 1981). Surveys for Sumatran rhinoceros in 1990 in a small area of the southern peninsula indicated 13-18 animals (AsRSG, 1995). If accurate, BBSNP may contain a substantial number of the estimated 200-300 Sumatran rhinos believed to remain in Indonesia. MacKinnon and Phillips (1993) reported that 121 bird species have been recorded in BBSNP, but suggest that the low figure is due to a lack of surveys in the area. The primary objectives of this survey were to develop baseline data on the presence and diversity of birds and mammals in protected lowland forest habitats of BBSNP.

\section{Methods}

We conducted surveys in. BBSNP between 7 and 24 March 1995, at the end of the rainy season. We surveyed areas on foot between Tampang and Tanjung Belimbing $(25 \mathrm{~km}), \mathrm{T}$. Belimbing to the Paya River $(20 \mathrm{~km})$, T.

* Scientific names of animals mentioned in the text are given in Table 1, and Appendices 1 and 2. 


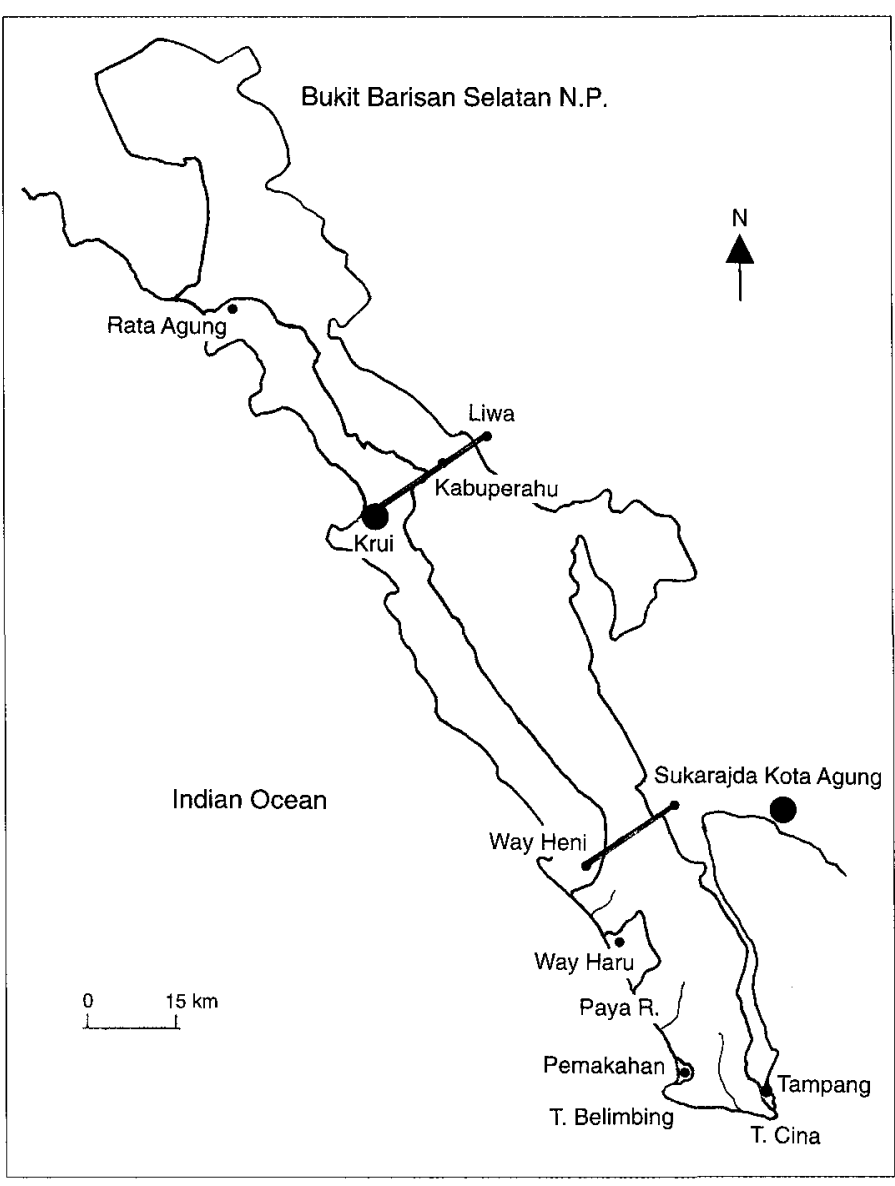

Figure 1. Map of Bukit Barisan Selatan showing villages, rivers and survey routes referred to in text.
Belimbing to T. Cina $(32 \mathrm{~km})$, Way Heni to Way Haru $(40 \mathrm{~km})$, and forests north of Rata Agung (15 km) (Figure 1). Surveys were conducted along established forest trails or elephant trails, and normally followed rivers or traversed areas between rivers. At each site, we recorded birds and mammals seen as well as indirect evidence (tracks, faeces, rooting). Indirect evidence is often the only indication that secretive forest mammals are present (Schemnitz, 1980; Rabinowitz, 1993). We also interviewed forest guards, hunters and collectors of forest products for information on tiger, clouded leopard, elephant and Sumatran rhinoceros. Finally, we surveyed literature for examples of faunal inventories in the region that might not have wide circulation.

\section{Results}

We verified the presence of 22 medium-sized to large mammals in areas surveyed (Table 1). Eleven mammals were recorded at most survey sites and the remaining 11 species were recorded at one or two survey sites. An additional 33 species have been reported from adjacent forests and agroforestry lands (Sibuea and Herdimansyah, 1993; Appendix 1)

\section{Sumatran rhinoceros}

We encountered recent rhino signs at three locations along the survey transects. In the vicinity of the Blambangan River we found footprints of at least two individuals, as well as scrapes and wallows. This area is a mosaic of open marshy areas, swamp forest and low- 
land forest on low ridges. Another set of prints was found at Tanjung Belimbing, adjacent to a proposed hunting concession on the park's eastern border. At the Paya River we found one set of prints that were less than 24 hours old; our guide said prints in three size classes are normally found in this area. No signs of rhino were found north of Paya River, although rhino tracks were found in damar Shorea javanica gardens near Krui in 1993 (Sibuea and Herdimansyah, 1993). Interviewees in Rata Agung said there had been no reports of rhino in the area for many years.

\section{Asian elephant}

Fresh elephant signs were encountered on every trail and elephants were seen and heard on several occasions. More elephant signs were encountered in the southern peninsula. Prints and faeces of young animals were seen on three surveys. Evidence was usually of lone individuals or groups of two or three animals. Based on interviews, we estimate approximately $100-150$ elephants in the park.

\section{Cats}

We found no tracks of tigers or clouded leopards during our survey. On two transects we found tracks of small, unidentified forest cats. There are periodic reports of tigers killing dogs and goats in the Belimbing and Way Heni areas, and tracks of tiger and clouded leopard have been reported in damar gardens near Krui on the edge of the park.

\section{Primates}

Siamang were abundant in all areas surveyed and family groups ranged from three to seven individuals. Less common were dark-handed gibbons, which we encountered only in the Paya River, Canguk River and Rata Agung areas. Lack of gibbons in the southern peninsula may reflect their need for continuous canopy forest. Small groups of banded langurs and silvered langurs were present in every site surveyed. Long-tailed macaques were most common in the southern peninsula. Pig-tailed macaques and the western tarsier were not

\begin{tabular}{lll}
\hline Common name & Scientific name & $\begin{array}{l}\text { Method of } \\
\text { identification }\end{array}$ \\
\hline Flying fox & Pteropus vampyrus & Photographs \\
Long-tailed macaque & Macaca fascicularis & Visual/vocalization \\
Silvered langur & Presbytis cristata & Visual/vocalization \\
Banded langur & Presbytis melalophus & Visual/vocalization \\
Dark-handed gibbon & Hylobates agilis & Visual/vocalization \\
Siamang & Hylobates syndactylus & Visual/vocalization \\
Malayan sun bear & Helarctos malavanus & Visual/tree damage \\
Hairy-nosed otter & Lutra sumatrana & Visual/tracks \\
Tiger & Panthera tigris & Local report \\
Clouded leopard & Neofelis nebulosa & Local report \\
Unidentified small cat & Felis sp. & Tracks \\
Asian elephant & Elephas maximus & Visual/faeces/tracks \\
Malayan tapir & Tapirus indicus & Tracks \\
Sumatran rhinoceros & Dicerorhinus sumatrensis & Tracks \\
Wild pig & Sus scrofa & Visual/tracks \\
Lesser mouse deer & Tragulus javanicus & Visual/tracks \\
Red muntjac & Muntiacus muntjak & Tracks \\
Sambar deer & Cerous unicolor & Tracks/vocalization \\
Domestic water buffalo & Bubalus bubalis & Visual/faeces/tracks \\
Malayan giant squirrel & Ratufa bicolor & Visual/vocalization \\
Plantain squirrel & Callosciurus notatus & Visual \\
Common porcupine & Hystris brachura & Quills \\
\hline
\end{tabular}

Table 1. Mammal species identified in Bukit Barisan Selatan National Park 
observed or heard, but both species have been reported in BBSNP and southern Sumatra (Payne et al., 1985; Whitten et al., 1987).

\section{Other mammals}

Tracks of sambar deer, red muntjac (barking deer) and mouse deer were found regularly on all surveys, and deer were observed on several occasions. In the north deer are hunted regularly but in the south no one admitted to hunting, possibly because we travelled with park guards. Wild pig Sus scrofa tracks and signs of rooting were also abundant at all sites. Domestic water buffalo were common from T. Belimbing to the Blambangan River. We found tracks of three or more Malayan tapir only in the Tampang-T. Belimbing area. Otter tracks were found at $\mathrm{T}$. Belimbing and eight hairy-nosed otters, including one albino, were observed near Way Haru. We encountered Malayan sun bears only between Way Heni and Way Haru and north of Rata Agung, although we received reports of their presence at all survey sites. We did not encounter signs of Indian wild dog, although it was believed common in BBSNP during the late 1970s. We also saw no evidence of civets, weasels, martens or badgers along the survey routes.

\section{Hornbills and other birds}

We confirmed the presence of seven species of hornbills in BBSNP. All sites contained at least five species. Most common were the helmeted, oriental pied, great and rhinoceros hornbills. Other surveys (Appendix 2) include two more species (white-crowned hornbill and wrinkled hornbill) making a total of nine species for the park. We located one active nest of the wreathed hornbill near the Paya River.

Our surveys contributed 58 new species to the list of known occurrences in BBSNP. The total bird list for BBSNP is 276 species out of 397 species believed to occur in Sumatra (Appendix 2). Most of the additions were forest interior birds. The diversity of lowland habitats (forest, swamp, coastal, marsh) provides habitat for a rich avian community in the park and we found relatively high diver- sity at all sites surveyed. Notably lacking from this list are nocturnal birds and montane species, which probably occur in the park.

\section{Human activity in the park}

Because of BBSNP's long border, patrolling is difficult and access to the park is relatively easy. Along the boundary near Tampang we encountered pit-sawing activity and most of the large dipterocarp trees were gone. Rattan was conspicuously absent at all sites surveyed and we encountered collectors of rattan and gaharu (fragrant resin from heartwood of Aquilaria spp.) in the forest near Rata Agung. There was evidence of expansion of agricultural lands across park boundaries at the enclave of Pemakahan and reports of illegal land clearance near the Kabuperahu enclave. We observed agricultural encroachment at Rata Agung and heard reports of similar problems near Krui. Residents of the enclave at Way Haru recently attempted to cut a road through the park but were stopped halfway by the Ministry of Forestry. On a larger scale, the construction of paved roads by the provincial government has been accompanied by extensive logging and resulted in the division of the park into three parts.

Human-wildlife interactions in BBSNP vary. Because there is no buffer zone, agricultural lands are immediately adjacent to, or inside the park. Livestock predation by tigers and clouded leopards occurs occasionally. Elephant depredation to rice paddies and coffee gardens is among the most pressing problems. This problem receives a great deal of publicity and there is pressure to institute culling and capture programmes to control elephants that move out of reserves (Jakarta Post, 1994; Pak Panjaitan, PHPA, pers. comm.). Hunting for local consumption occurs (especially deer species and great argus pheasant) but we heard of no instances of elephant or rhino poaching.

There is widespread local trade in edible swiftlet nests from the area. The Ministry of Forestry has issued collecting permits for sustainable exploitation at two sites, but most caves in the region are not owned and nests 
are freely collected and sold. Capturing wild birds for local bird trade is also common; one guide admitted to collecting hornbill chicks for sale.

\section{Discussion}

We consider the wildlife communities of lowland forests in BBSNP to be representative of intact lowland tropical rain forest. Surveys carried out in forests and damar gardens adjacent to the park indicate the presence of at least 52 forest mammal species, including Sumatran rhino, tiger and clouded leopard (Sibuea and Herdimansyah, 1993). We presume these species also occur within the park. The bird community is quite diverse, with approximately 70 per cent of Sumatra's avifauna occurring in the park's lowland forests.

The indigenous mammalian herbivore community in BBSNP is represented by Sumatran rhinoceros, Malayan tapir, Asian elephant. serow, wild pig and several deer species. The Sumatran rhinoceros may be more widespread than previously believed, but appears to be absent from the Rata Agung area. The BBSNP rhino population may be one of the most important remaining populations of this seriously endangered species. The elephant population appears to be healthy; it is widespread and breeding, and poaching is probably not a serious problem at this time. Although we lack population information for other herbivores, the survey indicates the continued survival of these species in the park.

Our surveys failed to find much evidence of mammalian carnivores in the primary forests of BBSNP, although we know that at least nine species occur in and around the park. One problem with a generalized survey of this nature is that most carnivore species are nocturnal and our surveys were diurnal. Civets may have been underrepresented because we did not sample secondary forest and edge habitats. Overall, however, the lack of signs (e.g. footprints, scrapes, faeces) indicates low densities for most carnivore species. It is possible that Indian wild dog, tiger and cloud leopard have been hunted heavily in the lowland forests or that densities have always been low in this region. More intensive surveys are needed to resolve the status of mammalian carnivores.

Bird diversity is high in the forests of BBSNP, and is comparable to the island of Java. Thiollay (1995) recorded more than 150 species during a short, but intensive survey of avian diversity in forests north of Rata Agung. BBSNP has avian diversity similar to wellstudied lowland sites in Borneo (MacKinnon and Phillipps, 1993), such as Danum Valley Conservation Area, Sabah, Malaysia (240 species), Kutai National Park, East Kalimantan, Indonesia (236 species) and Barito Ulu Research Area, Central Kalimantan, Indonesia (230 species). In Sumatra, only Gunung Leuser National Park exceeds the richness of BBSNP ( $>325$ species; Griffiths, 1994). Avian diversity in BBSNP may be comparable to Gunung Leuser NP once the nocturnal and montane birds are sampled.

Presence/absence data are useful for assessing the potential of an area for biodiversity conservation. They do not, however, reveal information concerning the population status of birds and mammals in these parks. Populations of exploited species, such as the tiger and Sumatran rhinoceros, may be present but under severe pressure and, possibly, facing local extinction. Populations of strawheaded bulbuls and white-rumped shamas are almost certainly declining due to capture for the bird trade, but trend data are lacking.

Apart from large-scale destruction of forests during the 1970s and 1980s, the interior forests of BBSNP appeared to be in very good shape. Pit-sawing and collecting local forest products are having impacts on certain species (e.g. trees of Dipterocarpaceae, rattan) along the borders. Encroachment will continue to be a problem around the park until issues of population growth and migration into the area are addressed. Currently, the Ministry of Forestry has neither the manpower, enforcement capability nor the training to address these landuse conflicts (USAID, 1994). Park headquarters are more than $20 \mathrm{~km}$ from the park and park guards do not live near the sites they are assigned to patrol. Most of the collectors and 
farmers we talked to believed that it was their right to use or cut forest as the need arose. Reconciliation of local needs with conservation is urgently needed in the area.

Protection and management activities should focus on illegal encroachment, nonsustainable exploitation of wildlife and forest products, and implementation of land-use zoning. Constructive relationships between park staff and local communities should be initiated, such that local communities develop an appreciation and support for the conservation of BBSNP. Because the Ministry of Forestry lacks the finances and expertise to implement most of these recommendations, they might concentrate their resources on patrolling and securing the park boundaries. Meanwhile, international assistance is necessary to develop monitoring capabilities, park management, staff training and community education programmes. Such an approach is imperative if Bukit Barisan Selatan National Park is to retain its splendour as a repository of biodiversity in Indonesia.

\section{Acknowledgements}

This survey was funded by the Wildlife Conservation Society. Permission for the survey was granted by Pak Effendi Sumardja, Director of Conservation Programmes, Ministry of Forestry (PHPA). Special thanks are given to Pak Panjaitan (Head of Lampung, Sumatra Regional Office, PHPA) and Pak Bambang Hartona (Head of Bukit Barisan Selatan National Park) for their help in organizing logistics. We also thank the many PHPA guards and local guides who accompanied us during our survey.

\section{References}

Anon. 1994. Saving Sumatra's elephants. Jakarta Post, 10 September 1994.

Asian Rhino Specialist Group. 1995. The Sumatran rhino in Bukit Barisan Selatan. Newsletter of the IUCN/SSC Asian Rhino Specialist Group, 1, 14.

Andrews, P. 1992. The Birds of Indonesia - A Checklist (Peters'sequence). Kukila checklist no. 1.

FAO. 1981. Barisan Selatan Game Reserve Management Plan, 1982-1987. FAO Field Report, Bogor, Indonesia.

Griffiths, M. 1994. Leuser National Park. Tien Wah Press, Singapore.

MacKinnon, J. and Phillipps, K. 1993. A Field Guide to the Birds of Borneo, Sumatra, Java and Bali. Oxford University Press, Oxford.

Payne, J., Francis, C.M. and Phillipps, K. 1985. A Field Guide to the Mammals of Borneo. Pencetak Weng Fatt Sdn. Bhd., Kuala Lumpur.

Rabinowitz, A. 1993. Wildlife Field Research and Conservation Training Manual. Wildlife Conservation Society, New York.

Schemnitz, S.D. (ed). 1980. Wildlife Management Techniques Manual. The Wildlife Society, Washington, DC.

Sibuea, T.T.H. and Herdimansyah, D. 1993. The Variety of Mammal Species in the Agroforest Areas of Krui (Lampung), Muara Bungo (Jambi). and Maninjau (West Sumatra). ORSTROM-BIOTROP Report, Bogor.

Thiollay, J.M. 1995. Are traditional agroforests an alternative for the conservation of rain forest bird diversity? Three case studies in Sumatra. Conservation Biology, 9, 335-353.

USAID. 1994. Policy Towards Protected Areas in Indonesia. Final Report. USAID Natural Resources Management Project Report No. 38.

Whitten, A.J., Damanik, S.J., Anwar, J. and Hisyam, N. 1987. The Ecology of Sumatra. Gadjah Mada University Press, Yogyakarta.

Timothy G. O'Brien and Margaret F. Kinnaird, Wildlife Conservation Society, International Programs, 185th and Southern Boulevard, Bronx, NY 10460, USA. 


\begin{tabular}{|c|c|c|c|}
\hline Family/species & English name & Family/species & English name \\
\hline Tupaiidae & & Ratufa bicolor & Malayan giant \\
\hline Tupaia glis & Common treeshrew & & squirrel \\
\hline ptilocercus lowii & Pentail treeshrew & Ratufa affinis & Giant squirrel \\
\hline $\begin{array}{l}\text { Cynocephalidae } \\
\text { Cynocephalus variegatus }\end{array}$ & Flying lemur & Sundasciurus hippurus & Horse-tailed squirrel \\
\hline Pteropodidae & & Sundasciurus lowii & Low's squirrel \\
\hline $\begin{array}{l}\text { Pteropus vampyrus } \\
\text { Chironax melanocephalus }\end{array}$ & $\begin{array}{l}\text { Large flying fox } \\
\text { Black-capped fruit bat }\end{array}$ & Tamiops maccllandii & $\begin{array}{l}\text { Himalayan striped } \\
\text { squirrel }\end{array}$ \\
\hline Rhinolophidae & & Muridae & \\
\hline Rhinolophus luctus & $\begin{array}{l}\text { Great woolly } \\
\text { horseshoe bat }\end{array}$ & Chiropodomys gliroides & $\begin{array}{l}\text { Common pencil-tailed } \\
\text { tree-mouse }\end{array}$ \\
\hline Hipposideridae & & Rattus exulans & Polynesian rat \\
\hline Hipposideros galeritus & Cantor's roundleaf bat & Rattus rattus & House rat \\
\hline Megadermatidae & & Rattus tiomanicus & Malaysian field rat \\
\hline Megaderma spasma & $\begin{array}{l}\text { Lesser false vampire } \\
\text { bat }\end{array}$ & $\begin{array}{l}\text { Hystricidae } \\
\text { Antherurus macrourus }\end{array}$ & Brush-tailed \\
\hline $\begin{array}{l}\text { Vespertilionidae } \\
\text { Pipistrellus stenopterus }\end{array}$ & $\begin{array}{l}\text { Narrow-winged } \\
\text { pipistrelle }\end{array}$ & $\begin{array}{l}\text { Hystrix brachyura } \\
\text { Ursidae }\end{array}$ & $\begin{array}{l}\text { porcupine } \\
\text { Common porcupine }\end{array}$ \\
\hline Phoniscus atrox & $\begin{array}{l}\text { Gilded groove- } \\
\text { toothed bat }\end{array}$ & $\begin{array}{l}\text { Helarctos malayanus } \\
\text { Mustelidae }\end{array}$ & Malayan sun bear \\
\hline Philetor brachypterus & $\begin{array}{l}\text { Narrow-winged } \\
\text { brown bat }\end{array}$ & $\begin{array}{l}\text { Lutra perspicillata } \\
\text { Mydaus javanensis }\end{array}$ & $\begin{array}{l}\text { Smooth otter } \\
\text { Malay badger }\end{array}$ \\
\hline Molossidae & & Viverridae & \\
\hline $\begin{array}{l}\text { Cheiromeles torquatus } \\
\text { Lorisidae }\end{array}$ & Naked bat & Arctogalidia trivirgata & $\begin{array}{l}\text { Small-tooth palm } \\
\text { civet }\end{array}$ \\
\hline Nycticebus coucang & Slow loris & Felidae & \\
\hline Tarsiidae & & Felis bengalensis & Leopard cat \\
\hline Tarsius bancanus & Western tarsier & Neofelis nebulosa & Clouded leopard \\
\hline Cercopithecidae & & Panthera tigris & Tiger \\
\hline Macaca fascicularis & Long-tailed macaque & Elephantidae & \\
\hline Macaca nemestrina & Pig-tailed macaque & Elephas maximus & Indian elephant \\
\hline Presbytis melalophus & Banded leaf monkey & Tapiridae & \\
\hline Presbytis cristata & Silvered leaf money & Tapirus indicus & Malayan tapir \\
\hline Hylobatidae & & Rhinocerotidae & \\
\hline $\begin{array}{l}\text { Hylobates agilis } \\
\text { Symphalangus syndactylus }\end{array}$ & $\begin{array}{l}\text { Black-handed gibbon } \\
\text { Siamang }\end{array}$ & $\begin{array}{l}\text { Dicerorhinus sumatrensis } \\
\text { Suidae }\end{array}$ & Sumatran rhinoceros \\
\hline Pholidota & & Sus scrofa & Wild pig \\
\hline Manis javanica & Pangolin & Tragulidae & \\
\hline Sciuridae & & Tragulus javanicus & Lesser mouse deer \\
\hline Aeromys tephromelas & Black flying squirrel & Tragulus napu & Greater mouse deer \\
\hline Petaurista petaurista & $\begin{array}{l}\text { Red giant flying } \\
\text { squirrel }\end{array}$ & $\begin{array}{l}\text { Cervidae } \\
\quad \text { Muntiacus muntjak }\end{array}$ & Red muntjac \\
\hline $\begin{array}{l}\text { Callosciurus nigrovittatus } \\
\text { Callosciurus notatus } \\
\text { Lariscus insignis }\end{array}$ & $\begin{array}{l}\text { Black-striped squirrel } \\
\text { Plantain squirrel } \\
\text { Three-striped ground } \\
\text { squirrel }\end{array}$ & Cerous unicolor & Sambar deer \\
\hline
\end{tabular}

Data from Sibuea and Herdimansyah (1993); nomenclature follows Payne et al. (1985). 
Appendix 2. Preliminary bird list for Bukit Barisan Selatan National Park

\begin{tabular}{|c|c|c|c|}
\hline Family/species & English name & Family/species & English name \\
\hline \multicolumn{2}{|l|}{ Pelicanidae } & Calidris ferruginea & Curlew sandpiper \\
\hline Pelicanus conspicillatus & $\begin{array}{l}\text { Australian white } \\
\text { pelican }\end{array}$ & $\begin{array}{l}\text { Calidris alba } \\
\text { Tringa hypoleucos }\end{array}$ & $\begin{array}{l}\text { Sanderling } \\
\text { Common sandpiper }\end{array}$ \\
\hline \multicolumn{2}{|l|}{ Fregatidae } & Philomachus pugnax & Ruff \\
\hline Fregata ariel & Lesser frigatebird & Burhinidae & \\
\hline \multicolumn{2}{|l|}{ Ardeidae } & $\begin{array}{l}\text { Esacus magnirostris } \\
\text { Laridae }\end{array}$ & Great thick-knee \\
\hline Ardea purpurea & Purple heron & Chlidonias hybrida & Whiskered tern \\
\hline Buterides striatus & Striated heron & Sterna hirundo & Common tern \\
\hline Egretta sacra & Pacific reef egret & Sterna albifrons & Little tern \\
\hline Egretta intermedia & Plumed egret & Anous stolidus & Brown noddy \\
\hline Egretta garzetta & Little egret & Columbidae & \\
\hline \multicolumn{2}{|l|}{ Ciconiidae } & Treron vernans & Pink-necked green- \\
\hline Ibis cinereus & Milky stork & & pigeon \\
\hline Aconia episcopus & Woolly-necked stork & Treron curvirostra & Thick-billed green- \\
\hline Leptoptilus javanicus & Lesser adjutant & & pigeon \\
\hline Leptoptilus dubius & Greater adjutant & Treron capellei & Large green pigeon \\
\hline \multicolumn{2}{|l|}{ Threskiornithidae } & Ducula aenea & $\begin{array}{l}\text { Green imperial } \\
\text { pigeon }\end{array}$ \\
\hline \multicolumn{2}{|c|}{ Anatidae } & Ducula bicolor & Pied imperial pigeon \\
\hline Dendrocygna arcuata & $\begin{array}{l}\text { Wandering whistling } \\
\text { duck }\end{array}$ & Ducula badia & $\begin{array}{l}\text { Mountain imperial } \\
\text { pigeon }\end{array}$ \\
\hline \multicolumn{2}{|l|}{ Pandionidae } & Macropygia ruficeps & Little cuckoo-dove \\
\hline Pandion haliaetus & Osprey & Streptopilia chinensis & Spotted dove \\
\hline \multicolumn{2}{|l|}{ Accipitridae } & Geopilia striata & Zebra dove \\
\hline Aviceda jerdoni & Jerdon's baza & Chalcophaps indica & Emerald dove \\
\hline Haliastur indus & Brahminy kite & Psittacidae & \\
\hline \multirow[t]{2}{*}{ Haliaeetus leucogaster } & $\begin{array}{l}\text { White-bellied sea- } \\
\text { eagle }\end{array}$ & $\begin{array}{l}\text { Psittinus cyanurus } \\
\text { Loriculus galgulus }\end{array}$ & \multirow{2}{*}{$\begin{array}{l}\text { Blue-rumped parrot } \\
\text { Blue-crowned } \\
\text { hanging parrot }\end{array}$} \\
\hline & $\begin{array}{l}\text { Grey-headed fish- } \\
\text { eagle }\end{array}$ & Cuculidae & \\
\hline Spilornis cheela & Crested serpent-eagle & Cacomantis sonneratii & Banded bay cuckoo \\
\hline Accipiter trivirgatus & Crested goshawk & Cacomantis merulinus & Plaintive cuckoo \\
\hline Ictinactus malayensis & Black eagle & Chrysoccoyx xanthorhynchus & Violet cuckoo \\
\hline Hieraaetus kiernii & Rufous-bellied eagle & Surniculus lugubris & Drongo cuckoo \\
\hline Spizeatus cirrhatus & $\begin{array}{l}\text { Changeable hawk- } \\
\text { eagle }\end{array}$ & $\begin{array}{l}\text { Eudynamys scolopacea } \\
\text { Phaenicophaeus diardi }\end{array}$ & $\begin{array}{l}\text { Asian koel } \\
\text { Black-bellied }\end{array}$ \\
\hline Spizeatus alboniger & Blyth's hawk-eagle & & malkoha \\
\hline \multirow{3}{*}{$\begin{array}{l}\text { Falconidae } \\
\quad \text { Microhierax fringillarius }\end{array}$} & & Phaenicophaeus curvirostris & Chestnut-breasted \\
\hline & Black-thighed & & malkoha \\
\hline & falconet & Phaenicophaeus chlorophaeus & Raffle's malkoha \\
\hline \multicolumn{2}{|l|}{ Phasianidae } & Phaenicophaeus javanicus & Red-billed malkoha \\
\hline Rollolus rouloul & Crested partridge & Phaenicophaeus sumatranus & Chestnut-bellied \\
\hline Lophura ignita & Crested fireback & & malkoha \\
\hline Gallus gallus & Red junglefowl & Phaenicophaeus tristis & Green-billed malkoha \\
\hline Argusianus argus & Great argus & Centropus sinensis & Greater coucal \\
\hline \multicolumn{2}{|l|}{ Rallidae } & Centropus bengalensis & Lesser coucal \\
\hline Porzana cinerea & White-browed crake & Caprimulgidae & \\
\hline \multicolumn{2}{|l|}{ Scolopacidae } & Eurpstopodus temminckii & Malaysian eared \\
\hline Numenius phaeopus & Whimbrel & & nightjar \\
\hline Numenius arquata & Eurasian curlew & Apodidae & \\
\hline Actitus hypoleucus & Common sandpiper & Collocalia fuciphage & Edible-nest swiftlet \\
\hline Arenaria interpres & Ruddy turnstone & Collocalia maxima & Black-nest swiftlet \\
\hline
\end{tabular}


Appendix 2. (continued)

\begin{tabular}{|c|c|c|c|}
\hline Family/species & English name & Family/species & English name \\
\hline Collocalia esculenta & White-bellied swiftlet & Capitonidae & \\
\hline Hirundapas cochinchinensis & $\begin{array}{l}\text { White-vented } \\
\text { needletail }\end{array}$ & Megalaima chrysopogon & $\begin{array}{l}\text { Gold-whiskered } \\
\text { barbet }\end{array}$ \\
\hline Apus pacificus & Fork-tailed swift & & \\
\hline Apus affinis & Little swift & Megalaima rafflesii & Red-crowned barbet \\
\hline Hemiprocnidae & & Megalaima mystacophanos & Red-throated barbet \\
\hline Hemiprocne longipennis & $\begin{array}{l}\text { Grey-rumped } \\
\text { treeswift }\end{array}$ & $\begin{array}{l}\text { Megalaima ortii } \\
\text { Megalaima henrici }\end{array}$ & $\begin{array}{l}\text { Black-browed barbet } \\
\text { Yellow-crowned }\end{array}$ \\
\hline Hemiprocne comata & Whiskered treeswift & & barbet \\
\hline Trogonidae & & Megalaima australis & Blue-eared barbet \\
\hline Harpactes duvaucelii & $\begin{array}{l}\text { Scarlet-rumped } \\
\text { trogon }\end{array}$ & $\begin{array}{l}\text { Megalaima haemacephala } \\
\text { Calorhamphus fuliginosus }\end{array}$ & $\begin{array}{l}\text { Coppersmith barbet } \\
\text { Brown barbet }\end{array}$ \\
\hline Harpactes kasumba & Red-naped trogon & Indicatoridae & \\
\hline Harpactes diardii & Diard's trogon & Indicator archipelagicus & Malaysian \\
\hline Harpactes oreskios & $\begin{array}{l}\text { Orange-breasted } \\
\text { trogon }\end{array}$ & Picidae & honeyguide \\
\hline Harpactes erythrocephalus & Red-headed trogon & Sasia abnormis & Rufous piculet \\
\hline Alconidae & & Celeus brachyurus & Rufous woodpecker \\
\hline Alcedo atthis & Common kingfisher & Meiglyptes tristis & Buff-rumped \\
\hline Alcedo meninting & Blue-eared kingfisher & & woodpecker \\
\hline Ceyx rufidorsa & $\begin{array}{l}\text { Rufous-backed } \\
\text { kingfisher }\end{array}$ & Meiglyptes tuckii & $\begin{array}{l}\text { Buff-necked } \\
\text { woodpecker }\end{array}$ \\
\hline Ceyx erithacus & $\begin{array}{l}\text { Black-backed } \\
\text { kingfisher }\end{array}$ & Dryocopus javensis & $\begin{array}{l}\text { White-bellied } \\
\text { woodpecker }\end{array}$ \\
\hline Lacedo pulchella & Banded kingfisher & Hemicircus concretus & Grey and buff \\
\hline \multirow[t]{2}{*}{ Halcyon capensis } & Stork-billed & & woodpecker \\
\hline & kingfisher & Blythipius rubiginosus & Maroon woodpecker \\
\hline Halcyon smyrnensis & $\begin{array}{l}\text { White-throated } \\
\text { kingfisher }\end{array}$ & Picus mentalis & $\begin{array}{l}\text { Checker-throated } \\
\text { woodpecker }\end{array}$ \\
\hline \multirow[t]{2}{*}{ Halcyon pileata } & Blacked-capped & Picus flavinucha & Geater yellownape \\
\hline & kingfisher & Picus puniceus & Crimson-winged \\
\hline Todirhamphus chloris & Collared kingfisher & & woodpecker \\
\hline \multirow[t]{2}{*}{ Actenoides concretus } & Rufous-collared & Picus miniaceus & Banded woodpecker \\
\hline & kingfisher & Dinopium javanense & Common goldenback \\
\hline \multicolumn{2}{|l|}{ Maropidae } & Dinopium rafflesii & Olive-backed \\
\hline \multirow[t]{2}{*}{ Merops viridis } & Blue-throated bee- & & woodpecker \\
\hline & eater & Mulleripicus pulverulentus & Great slaty \\
\hline \multirow[t]{2}{*}{ Nyctyornis amictus } & Red-bearded bee- & & woodpecker \\
\hline & eater & Reinwardtipicus validus & Orange-backed \\
\hline Eurystomus orientalis & Dollarbird & & woodpecker \\
\hline Bucerotidae & & Eurylaimidae & \\
\hline \multirow[t]{2}{*}{ Anorrhinus galeritus } & Bushy-crested & Corydon sumatranus & Dusky broadbill \\
\hline & hornbill & Cymbirhynchus & Black and red \\
\hline \multirow[t]{2}{*}{ Berenicornis comatus } & White-crowned & macrorhynchus & broadbill \\
\hline & hornbill & Eurylaimus javanicus & Banded broadbill \\
\hline Rhyticeros undulatus & Wreathed hornbill & Eurylaimus ochromalus & Black and yellow \\
\hline Rhyticeros corrogatus & Wrinkled hornbill & & broadbill \\
\hline Anthracoceros malayanus & Asian black hornbill & Serilophus lunatus & Silver-breasted \\
\hline Anthracocerus albirostris & Oriental pied hornbill & & broadbill \\
\hline Buceros rhinoceros & Rhinoceros hornbill & Psarisomus dalhousie & Long-tailed broadbill \\
\hline Buceros bicornis & Great hornbill & Calyptomena viridis & Green broadbill \\
\hline Rhinoplex vigil & Helmeted hornbill & & \\
\hline
\end{tabular}


Appendix 2. (continued)

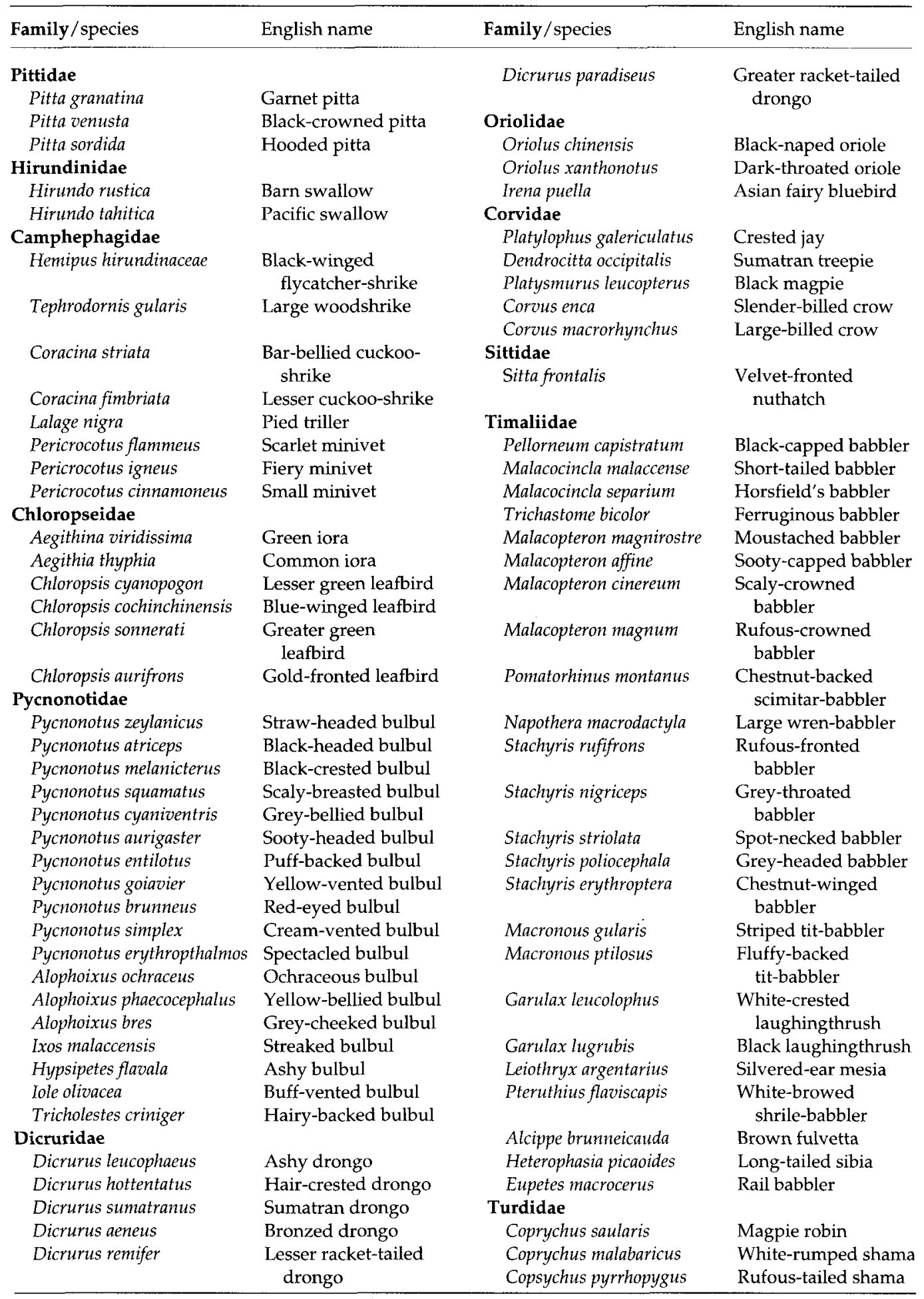


Appendix 2. (continued)

\begin{tabular}{|c|c|c|c|}
\hline Family/species & English name & Family/species & English name \\
\hline Enicurus ruficapillus & $\begin{array}{l}\text { Chestnut-naped } \\
\text { forktail }\end{array}$ & $\begin{array}{l}\text { Anthus novaeseelandiae } \\
\text { Laniidae }\end{array}$ & Common pipit \\
\hline Enicurus leschenaulti & $\begin{array}{l}\text { White-crowned } \\
\text { forktail }\end{array}$ & $\begin{array}{l}\text { Lanius tigrinus } \\
\text { Sturnidae }\end{array}$ & Tiger shrike \\
\hline Myiophoneus glaucinus & $\begin{array}{l}\text { Sunda whistling- } \\
\text { thrush }\end{array}$ & $\begin{array}{l}\text { Aplonis panayensis } \\
\text { Family/species }\end{array}$ & $\begin{array}{l}\text { Philippine glossy } \\
\text { English name }\end{array}$ \\
\hline \multicolumn{4}{|l|}{ Myiophoneus caeruleus } \\
\hline Sylviidae & & & starling \\
\hline Abroscopus superciliaris & $\begin{array}{l}\text { Yellow-bellied } \\
\text { warbler }\end{array}$ & $\begin{array}{l}\text { Gracula religiosa } \\
\text { Nectariniidae }\end{array}$ & Hill myna \\
\hline Phylloscopus coronatus & $\begin{array}{l}\text { Eastern crowned } \\
\text { warbler }\end{array}$ & $\begin{array}{l}\text { Anthreptes simplex } \\
\text { Anthreptes malacensis }\end{array}$ & $\begin{array}{l}\text { Plain sunbird } \\
\text { Brown-throated }\end{array}$ \\
\hline Orthotomus sutorius & Common tailorbird & & sunbird \\
\hline Orthotomus atrogularis & $\begin{array}{l}\text { Dark-necked } \\
\text { tailorbird }\end{array}$ & $\begin{array}{l}\text { Anthreptes rhodolaema } \\
\text { Anthreptes singalensis }\end{array}$ & $\begin{array}{l}\text { Red-throated sunbird } \\
\text { Ruby-cheeked }\end{array}$ \\
\hline Orthotomus sericens & $\begin{array}{l}\text { Rufous-tailed } \\
\text { tailorbird }\end{array}$ & Hypogramma & $\begin{array}{c}\text { sunbird } \\
\text { Purple-naped }\end{array}$ \\
\hline Prinia flaviventris & Yellow-bellied prinia & hypogrammicum & sunbird \\
\hline Prinia familiaris & Bar-winged prinia & Nectarina jugularis & Olive-backed sunbird \\
\hline Cisticola juncidis & Zitting cisticola & Aethopyga siparaja & Crimson sunbird \\
\hline Muscicapidae & & Aethopyga mysticalis & Scarlet sunbird \\
\hline Rhinomyias olivacea & $\begin{array}{l}\text { Fulvous-chested } \\
\text { rhinomyias }\end{array}$ & Arachnothera crassirostris & $\begin{array}{l}\text { Thick-billed } \\
\text { spiderhunter }\end{array}$ \\
\hline Rhinomyias umbratilis & $\begin{array}{l}\text { Grey-chested } \\
\text { rhinomyias }\end{array}$ & Arachnothera robusta & $\begin{array}{l}\text { Long-billed } \\
\text { spiderhunter }\end{array}$ \\
\hline Cyanoptila cyanomelana & $\begin{array}{l}\text { Blue-and-white } \\
\text { flycatcher }\end{array}$ & Arachnothera flavigaster & $\begin{array}{l}\text { Spectacled } \\
\text { spiderhunter }\end{array}$ \\
\hline Cyornis rufigastra & $\begin{array}{l}\text { Mangrove blue } \\
\text { flycatcher }\end{array}$ & Arachnothera chrysogenys & $\begin{array}{l}\text { Yellow-eared } \\
\text { spiderhunter }\end{array}$ \\
\hline Cyornis concreta & Dark-blue flycatcher & Arachnothera longirostra & Little spiderhunter \\
\hline Cyornis unicolor & Pale-blue flycatcher & Dicaeidae & \\
\hline Cyornis turcosus & $\begin{array}{l}\text { Malaysian blue } \\
\text { flycatcher }\end{array}$ & Prionochilus maculatus & $\begin{array}{c}\text { Yellow-breasted } \\
\text { flowerpecker }\end{array}$ \\
\hline Rhipidura perlata & Spotted fantail & Prionochilus percussus & Crimson-breasted \\
\hline Terpsiphone paradisi & $\begin{array}{l}\text { Asian paradise } \\
\text { flycatcher }\end{array}$ & Dicaeum cruentatum & $\begin{array}{l}\text { flowerpecker } \\
\text { Scarlet-backed }\end{array}$ \\
\hline Eumyias thalassina & Verditer flycatcher & & flowerpecker \\
\hline Eumyias indigo & Indigo flycatcher & Dicaeum concolor & Plain flowerpecker \\
\hline Muscicapa dautrica & $\begin{array}{l}\text { Asian brown } \\
\text { flycatcher }\end{array}$ & Dicaeum trignostigma & $\begin{array}{l}\text { Orange-bellied } \\
\text { flowerpecker }\end{array}$ \\
\hline Ficedula dumetoria & $\begin{array}{l}\text { Rufous-chested } \\
\text { flycatcher }\end{array}$ & Dicaeum chrysorrheum & $\begin{array}{l}\text { Yellow-vented } \\
\text { flowerpecker }\end{array}$ \\
\hline Niltava grandis & Large niltava & Dicaeum ignipectus & Fire-breasted \\
\hline Hypothymus azurea & Black-naped monarch & & flowerpecker \\
\hline Ptilentoma pyrhopterum & $\begin{array}{l}\text { Rufous-winged } \\
\text { philentoma }\end{array}$ & $\begin{array}{l}\text { Zosteropidae } \\
\text { Zosterops palpebrosus }\end{array}$ & Oriental white-eye \\
\hline Philentoma velatum & $\begin{array}{l}\text { Maroon-breasted } \\
\text { philentoma }\end{array}$ & $\begin{array}{l}\text { Ploceidae } \\
\text { Lonchura leucogastra }\end{array}$ & White-bellied munia \\
\hline Motacillidae & & Lonchura malacca & Black-headed munia \\
\hline Motacilla cinerea & Grey wagtail & Lonchura maja & White-headed munia \\
\hline Motacilla flava & Yellow wagtail & & \\
\hline
\end{tabular}

Compiled from FAO (1981), Thiollay (1995) and this survey. Nomenclature follows Andrews (1992). 